\title{
Electrification Using a Hybrid Microgrid System for Mutate Masisi Community-A Demand Side Response
}

\author{
Miriam Madziga ${ }^{1^{*}}$ and Abdulla Rahil ${ }^{2}$ \\ ${ }^{1}$ Faculty of Technology, The Gateway Leicester LE1 9BH, United Kingdom \\ ${ }^{2}$ Institute of Energy and Sustainable Development (IESD), The Gateway Leicester LE1 9BH, United Kingdom
}

"Corresponding author: Madziga M, De Montfort University, Leicester UK /Faculty of Technology, The Gateway Leicester LE1 9BH, United Kingdom, Tel: +254738974888; E-mail: mmadziga@yahoo.co.uk

Received: October 16, 2018; Accepted: October 26, 2018; Published: November 05, 2018

Copyright: @ 2018 Madziga M, et al. This is an open-access article distributed under the terms of the Creative Commons Attribution License, which permits unrestricted use, distribution, and reproduction in any medium, provided the original author and source are credited.

\begin{abstract}
The current use and shift from fossil fuels to renewable resources is not the only reason for adopting alternative energy resources. Certain rural communities lack the access to the available resources, due to multiple factors: proximity, technical-skill, access, off-grid systems and socio-economic factors. Even though the most frequently sort out renewable system for electrification is solar energy, particularly for temperate climates with vast abundance and high solar radiation. The contribution of solar energy harnessed using photovoltaic panels has been significantly beneficial to remote areas off-grid with no access to main grid system; other challenges encountered are varied, depending on the project outcome. Some of which are cost optimization and storage units. The demand and supply side response for electrification has largely been determined by the prevailing market rate. A demand side response (DSR) approach is applied to tackle this challenge, this determines the current energy requirements of the community and identifies the optimal hybrid system with or without storage. For this analysis, two systems scenarios were modelled: (1) PV with Diesel Generator System and (2) PV with Battery Storage System.

In each system four photovoltaic panels (PV) sizes which were chosen, tested and analysed for optimal sizing. The PV sizes were $0.4 \mathrm{~kW}, 0.6 \mathrm{~kW}, 0.8 \mathrm{~kW}$ and $1 \mathrm{~kW}$. The optimization between these sizes was built based on three main objectives - (a) Energy Demand Satisfaction /Demand Side Response (b) System Cost and (c) pollution. In both system scenarios, the optimal size was the $1 \mathrm{~kW}$ with battery storage and $1 \mathrm{~kW}$ with diesel generator. A further comparative analysis was carried out between the two systems; when the diesel generator is used and when the battery is applied. Both scenarios can sufficiently meet the demand without any considerable interruption, but disparities exist between them in relation to cost and technical optimization. A highly significant difference in the costs between the two system scenarios were detected. The total cost in PV-Battery system represents only $26 \%$ of the PV system. Also, the PV and Battery system does not release any harmful emissions compared with nearly 6 $\mathrm{tCO}_{2} /$ year in the PV with Diesel system.
\end{abstract}

Keywords: Modern power systems; Clean energy; Solar energy electrification; Hybrid renewable systems; Demand side response water quality

\section{Introduction}

The demand of energy is equally as important as the need to balance the energy systems generation for sustainable uses. In areas lacking access to one or more energy systems, a combined hybrid approach is usually applied and developed. The continuous shift on reliance of fossil fuel as the major source of energy generation has paved way for research into alternative renewable sources which is usually used in isolation or combined with current available resources [1-9]. The Hybrid Renewable Energy Systems (HRES) is a technique used for combination and it has gained reputable popularity not only due to its sustainable benefits but also its flexibility for usage in conjunction to already established energy systems. The HRES is a combined system of two or more renewable and/or non-renewable energy sources often used for areas with little or no access to electricity [9]. The design and modelling of the HRES is unique to each case study and often used in energy balancing of systems for stability and reliability with its main drivers as: system costs, system optimization and emission reduction [10-17]. Despite the continuous research carried out on improving efficiency, performance and optimality [18-22]. The main challenge with establishing a highly successful performance-based system hinges on energy balance and management- this is where the demand side response plays a crucial role. DSR is a flexible approach to energy management which manages load and voltage profiles [1]. In a hybrid system the varied continuous and flexible integration of conventional and renewable energy sources such as solar, wind, etc. means there is no one size fits all standard, but when a system design solution is aimed at solving an optimization problem it yields the best possible outcome [14,23-26]. Determining the optimal solution is highly dependent on the case study, dynamic variables, energy balance and management and other parameters necessary, or as defined by the researcher $[11,15]$.

\section{Hybrid Renewable Energy Systems (HRES)}

There are multiple processing techniques for achieving optimal condition in operation and parameter classifications, particularly when dealing with multiple components in the HRES. There are algorithm based energy technique to size the photovoltaic (PV), a software modelling technique, a linear programming technique, a probability technique, an iterative technique, analytical model, dynamic technic, and multi-objective genetic algorithm technique, and numerical 
algorithm based technique can be used for unit sizing and costs analyses, etc. $[27,28]$. In developing the HRES combination for wind and solar PV; the state of design, operation, control requirement, performance analysis of demonstration systems and efficient power converters; the total life costs were significantly reduced [29,30]. The energy resources combination also proved to be a more reliable source of electricity supply and this reduced the bank battery and diesel requirements all together [31]. In another study of the HRES, the design process leveraged on using different component parts for the purpose of minimizing lifecycle costs, a criteria selection was determined to produce a combination of trade-off between reliability, costs and minimum use of diesel generator sets. The optimal combination point was determined at a unit costs for the case area where the micro-wind-hydro system was found to be the optimal combination for electricity [16]. This maintains a $100 \%$ renewable energy sources while eliminating the diesel generator [8]. In another feasibility study to generate electricity for the Grimsey Island, the wind-to-hydrogen system was examined for optimal system solution. Three main scenarios were designed: (i) wind-diesel (ii) wind-dieselhydrogen and (iii) wind-hydrogen systems; the outcome reveled and suggested a successful succession in installation from (i) to (iii) in that order. In a 20-year period, the running costs of system were significantly reduced, not without substantial investments at the onset. From a practical perspective, the wind-diesel -hydrogen system had the lowest operational cost from the configuration design of the three scenarios. The costs of renewable technologies and oil price fluctuations were also a major determinate for the progressive direction (or otherwise) of HRES in the future [13,32-34]. The technoeconomic feasibility study of a PV-wind power plant construction for electric and hydrogen production for the Hendijan area, Iran to examine the potential of available energy sources indicated strong potential for renewable energy production especially - wind power for hydrogen production. The system combination was economically feasible as the amount of power output of the power plan for one wind turbine, $4 \mathrm{~kW}$ generator and $4 \mathrm{~kW}$ photovoltaic were equal to the costs of hydrogen obtained per year [35]. In the optimization of PVbiomass-diesel and grid base hybrid energy systems for rural electrification modelled with HOMER for Jhawani village, Tezpur area, India, it was aimed at investigating the economic impact of a decentralized renewable energy base system with no grid extension [36-40]. The design optimizes by configuring different load profiles, costs of energy at different peak load, energy demand profile and grid availability. The electricity costs depend on load factor; which has an inverse relationship between peak load/energy demand and cost of electricity generation. The comparison between grid extension and offgrid is a matter of economic perspective in decision making $[7,12]$. Overall, the hybrid energy system is a feasible reliable source, the result shows the optimal scenario to be the biomass gasification system rather than a photovoltaic system. There is also an emphasis on the unforeseen challenges that may arise from practical application of proposed configurations such as its environmental and economic feasibility in the long-run [21,22], and subsequently, its design methodology as well to replace the conventional plants with the renewable plants in an analyzed performance level for off-grid locations [41-47].

In the off-grid location of the Selangor, Malaysia regions, the windpv-diesel-battery system designed considered a load size profile of 33 $\mathrm{kWh} /$ day and peak load of $3.9 \mathrm{~kW}$, with net present economic costs, available energy sources and size, and $\mathrm{CO}_{2}$ emissions. The net present costs and $\mathrm{CO}_{2}$ emission was reduced by up to $29.65 \%$ and 16 tons per year in comparison to the conventional power plants. This can also be applicable to areas with similar climatic conditions [48]. The shift to encapsulate and accommodate off-grid and micro grid renewables systems is fast becoming the main stay for local communities without access [49-52]. This shifts the focus and burden of responsibility of electrification from large scale to small scale and prevents spike in the costs of electricity which is argued to be easily adopted through the demand-side response approach (DSR) [53-56]. The DSR however is argued to be a less overwhelming and manageable model for instilling a sense of ownership and partnership while providing the community's essential need for energy for electrification and other energy intensive activities $[3,6]$.

\section{Demand Side Response (DSR)}

DSR is also known as the Load Management Profile which is often a virtual interface and was designed in the early 1980's by Clark Gelling of Electric Power Research Institute, USA. Thereafter, several projects and research studies emerged which considered the benefits, future opportunities and technology devices for DSR management. This was developed to change the profile of power demand to ensure security, improve continuity [57,58]. The Federal Energy Regulatory Commission (FERC) defines Demand Side Response (DSR) as the changes in electric use by demand-side resources from their normal consumption pattern in response to the changes in the price of electricity or to incentive payments designed to induce lower electricity use at times of either: (i) high wholesale market prices, (ii) or when system reliability is jeopardized. Usually the conventional mode of getting consumers and end users to change their pattern and usage of electricity costs is through increases of tariff while this does not account for the grid overload (in terms of national power plants) or the higher production costs by suppliers [59-63]. DSR methodologies continually emerge on a quest to optimize solutions and incorporate into renewable energy resources for more interconnectedness of energy systems, optimized usage and saving potential, particularly on financially cumbersome projects [11]. DSR can be modelled into both the supplier and demand end point and is further divided into two main types: Energy Efficiency (EE) and Demand Response (DR). Other DSR methodologies can be determined based on the overall goal and outcome of project as with the case study area of Kuwait which aimed at electricity supply reduction by restriction of wattage per area. Other measures where applied to reduce the energy usage and peak power requirement through an optimize operation technique $[1,6]$. In an application of the DSR model to optimize electricity costs caused by peak performances [49] the results yielded huge financial benefits, cost minimization and higher economic performance. DSR is argued to reduce energy demand use by posing a restriction on extent and quantity of electricity supply, asserts that the use of the strengths, weakness, opportunities and threats (SWOT) analysis can be introduced as an incentive-based demand response to measure its effectiveness [17-19]. This enables the SWOT analysis to measure identifiable and create a shift and shedding of the electrical load [48] which can serve as a trade-off of costs and inconveniences between the EE and DR [43]. The DSR enables end user active participation in daily energy usage and promotes electricity saving schemes while shifting the burden of generation, transmission, distribution and billing from huge power operating plants largely run by fossil fuels [64-66]. 


\section{The management approach}

The flexible approach to energy management is beneficial for low to medium income communities as energy is supplied when required for usage in a costs effectiveness manner. Therefore, a well-established energy management technique form both ends of the supply and demand working both ends to the middle is crucial. There are many other management approaches [67-69]. however in the demand side management approach (DSM), the Demand Response (DR), Energy Efficiency (EE) and Distributed Generation (DG) are considered in unison for a more detailed comprehensive and systematic framework. Within this approach the EE is regarded as the focal framework for improving performance, operation, equipment and technology (POET); the DR is an incentivized program and tariff systems which motivates end-users change their electricity consumption style and pattern - this encapsulates processes such as personalized payment plan, re-structured tariff or pay as you go schemes for a better optimal value. DR incentive based program is a user participation program which promotes benefits of costs and emissions savings, sense of engagement, ownership and accountability while minimize operating costs $[3,70,71]$. The potential of a DR is determined by climatic conditions, weather, economic situations and availability of changes at a particular time and response rates to these changes as a result of other unforeseen factors [48]. In minimization techniques, energy consumption and cost are used as the main objectives for minimization [67]. however, the objective function can be defined as the consumers' participation in changing their consumption behaviour in relation to traditional energy usage; while the DG is the distribution and storage channelling of energy $[5,67]$.

\section{Policy and barriers}

In relation to policy it is not necessary that the DSR policy for one country is readily and easily applicable and successful when applied in another country. Other factors influence the success rates due to its sporadic nature and implementation in other countries, subject to proper regulation and involvement of energy and resource distribution companies [48-49]. The most common barriers to entry and application of new systems can be lumped as: social, economic and technical barriers $[10,25,26]$. This is often countered by infusing the current existing market structure with the newly proposed design to ease transition [64]. The key concept for infusion is flexibility and DSR allows for electricity and smart grid flexibilities and security in operation. This is where the dynamic and smart interactions already exist in market structures however, certain barriers are expected and encountered such as gaps in data, lack of information, communication, technology (sensing, computing) and infrastructure and technical know-how (depending on the complexity of system) $[20,24,70]$.

\section{Price based demand response}

In economic analysis, supply (SS) is traditionally seen to follow demand (DD) and the point of intersection of SS and DD is the equilibrium point [38]. This established when the electrical energy required is adequately supplied. The imbalance of the SS and DD affect prices both in long and short term [59], and this causes the supply of electricity to become time sensitive since it is required at the point of source. Any increase in demand will force the supplier to meet up with the demand of electricity and make adjustments within a short space of time, assuming there are no interruptions, shortages, power cuts and disturbance within the system $[48,49]$. This shifts leads to excess demand and sets price below the equilibrium price. When price is low, many consumers demand more but the suppliers are not able to supply it; thereby causing a change in SS. This movement along the SS curve occurs when there is a change in quantity supplied caused by a change in price, as characterized by (diesel and fuel prices). During periods of shortages, the point at which the supplier attempts to match demand for electricity is the point when the supplier market diversifies into sourcing for alternative complementary resources and products to substitute for time lags to bring it back to equilibrium point [45]. This often means the supply side assets of production and distribution of assets are required. There are fluctuations in electricity prices often caused by numerous factors, the common being rise and increase in costs, infrastructure and resources generated by a peak in demand. Suppliers seek to alleviate peak demands all together, and since the demand spikes serves as a price signal, the costs of the spike is associated with a rise in peak seen as a function of time [37,39]. Most times, the price is determined by regulations and price index for crude oil prevailing at that point in time, in relation to access. This is often a contributing factor as it creates scarcity, limits fluid access and price fluctuations [5] within this market structure. The overall costs associated with overexertion and waste of resources, commitments and unnecessary hurdles is eliminated when adopting a demand side hybrid approach [50].

\section{Challenges-surplus energy}

The main challenge the DSR addresses is the usage and storage of surplus energy [10]. Tackling the challenge from the perspective of a DSR in a micro grid system, ensures that the surplus energy harness is not wasted due to either additional storage costs or inability to supply surplus to a grid system. Recent research also highlights other plausible potentials for usage of surplus energy through the renewable energy trading initiative, with a feasible potential of transferability of demand side response policies between countries [68], local environments and communities which fosters more trading opportunities and a qui-pro quo relationship similar to a trade-by-barter policy, based on a multi criteria decision making analysis (MCDM). The main determining factors are framed within the context of market structure, climate, system structure, energy demands and with emphasis on policy evaluation [70]. On the community level, challenges encountered deals with establishing a flexible mechanized system responsive to changes in power prices of different hours. This can be adopted using a control strategy and dispatch system [30], in the HRES. There are considerable amount of research ongoing on system configurations developed to signal and respond to price changes and fluctuations and energy systems calibrated to enhance heating and cooling sensors, for responsiveness to time $[33,36]$. Meanwhile in a fully functional grid system, the time lag does not exist, unlike for areas without access which requires a more detailed response and/or higher energy potential storage system. The consumer profile shifts to adapt to new prices and minimize electricity bills $[4,51]$ The DSR price pool and the most binding method for each individual is the Marginal Cost (MC) in a competitive marker structure, where the presence of other participators capable of affecting market prices eliminates complete competition $[6,10]$

\section{Materials and Methods}

Mutate Masisi is a small community in Limpopo province, South Africa located on latitude $22.5108^{\circ} \mathrm{S}, 30.8039^{\circ} \mathrm{E}$, with a population of approximately 100 and main sustenance as agriculture and farming. There is a gradual decline in total population due to migration 
Citation: Madziga M, Rahil A (2018) Electrification Using a Hybrid Microgrid System for Mutate Masisi Community-A Demand Side Response. J Environ Anal Toxicol 8: 590. doi:10.4172/2161-0525.1000590

Page 4 of 14

overtime, particularly to other regions with basic infrastructural facilities for water supply and electricity. The socio-economic challenges associated with lack of amenities hinders economic growth, in so far as to ensure health and welfare of the community. This is a community with very little literature substantial to draw inferences, however the necessary data retrieved is examined and used to determine a demand side response approach to providing electrification using a hybrid micro system to aid in its sustenance culture (Figures 1 and 2) [32].

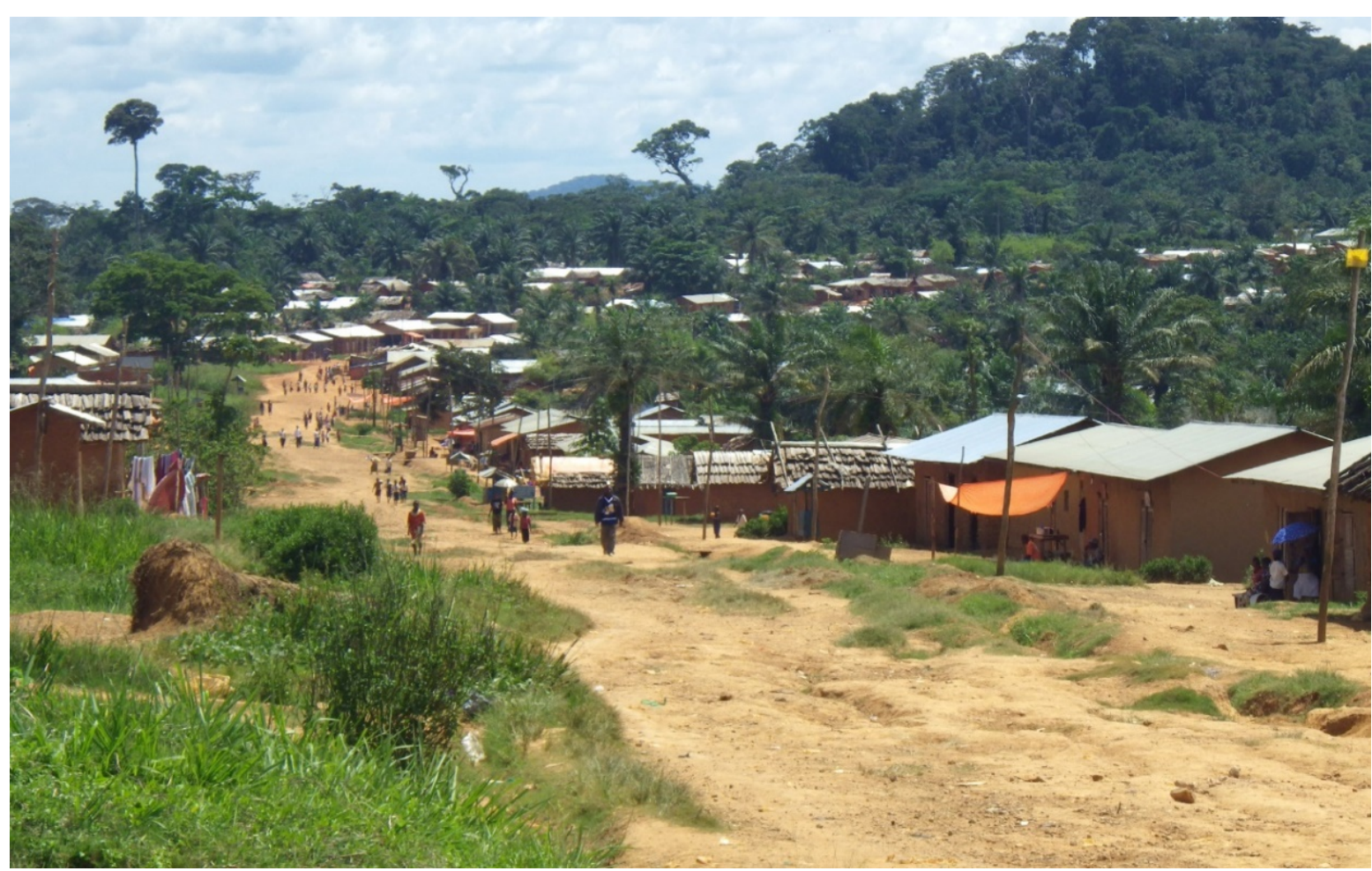

Figure 1: Scenarios of the Mutate Masisi Community.

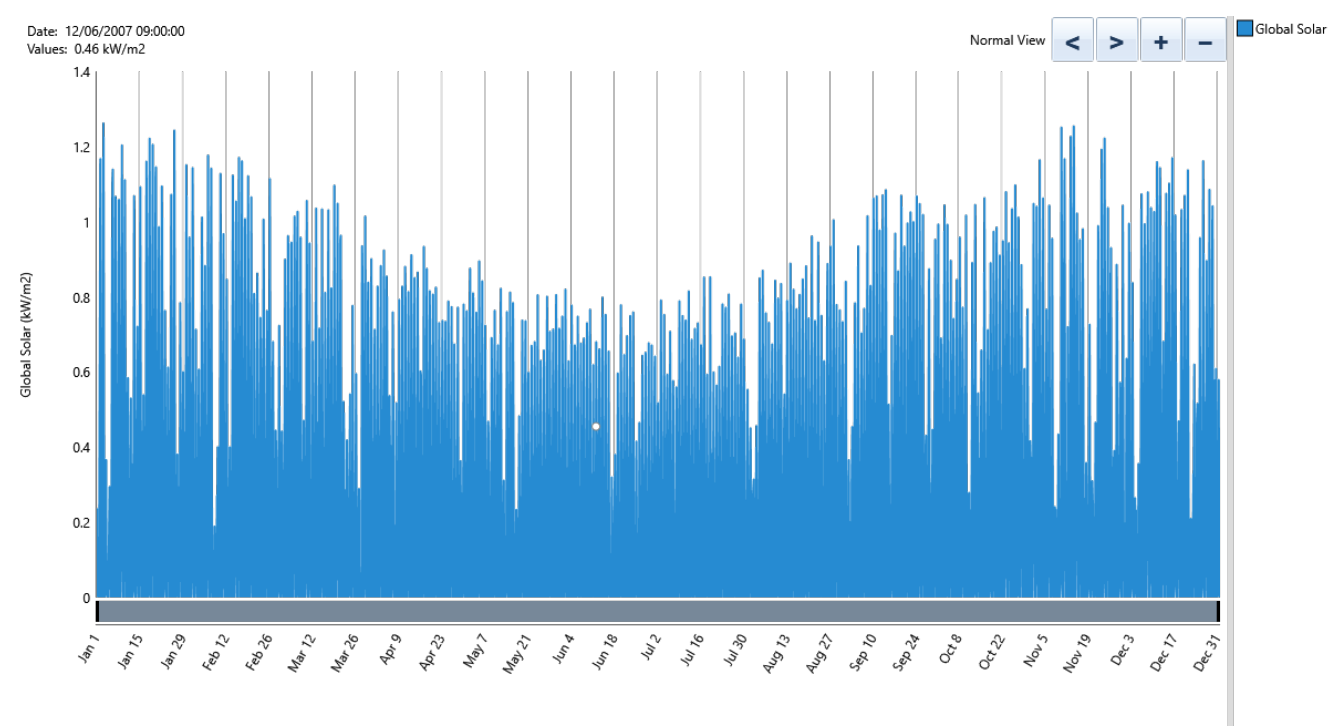

Figure 2: Yearly Solar Irradiance pattern for Mutate Masisi Area 


\section{Data collection}

The data collection of solar energy availability potential energy requirement and cost assumptions were determined.Solar radiation data for specific location can be extracted by different means, for example, solar radiation can be obtained from metrological stations which was distributed across the country in question; or it can also be extracted by transporting the latitude and longitude figures of the region into the NASA portal found on the website. The same steps are applied for calculating the PV Watts as provided by the NREL where solar radiation for the region of study are obtained [32,64,65]. The global solar radiation data for Mutate Masisi is shown in Figure 2 which highlights the pattern by hour of the day and day of the year from January to March and September to December as the peak months for solar radiation while from April to August exhibits the lowest solar radiation.

\section{Energy demand}

There is no available grid system for electricity for the population of 100 in this community. The predominant need for consistent electricity supply is required to accommodate the basic lifestyle of the community for daily use. These are for: (i) water pumping for water generation for drinking, domestic and agricultural uses; this is usually generated by a pump mechanism powered by diesel generator. (ii) Mobile Phone Charging and (iii) House Lighting at night time.

\section{Basic assumptions}

The lack of data on this community is a challenge, so the researcher builds up on the available information retrieved for further analysis. The population of 100 is further subdivided into family units to estimate the number of houses. The average family size is determined as 5 people per household with a total of 20 houses. The house sizes is not determined, it is also assumed that the community runs a community-based living and rules of engagement apply; where the presiding chieftain (leader)is available to assert a measure of authority. The local type of employment is predominantly simple agriculture which requires minimal irrigation and animal husbandry. The electrical demand will be required for lighting, mobile phone charging and water pumping. One mobile cell phone is assumed for each household, and one lamp per household is assumed for electricity supply. One water pumping device is assumed for the entire village and this is run for 3 hours. These assumptions are made to enable a simple arithmetic assumption for demand estimation (Table 1).

\begin{tabular}{|l|l|l|l|l|l|l|}
\hline Device & Load Point & Rating (W) & Load (W) & Operation Time (h) & $\begin{array}{l}\text { Load } \\
\text { (h) }\end{array}$ & $\begin{array}{l}\text { Duration } \\
\text { Energy Demand } \\
\text { (Wh/day) }\end{array}$ \\
\hline Lighting [2,44,65] & 17 & 20 & 340 & $17: 00-21: 00$ & 5 & 1700 \\
\hline Mobile Phone [32] & 17 & 25 & 425 & $7: 00-10: 00$ & 3 & 1275 \\
\hline Water Pumping [44,64,66] & 2 & 598 & 1196 & $7: 00-10: 00$ & 3 & 3588 \\
\hline
\end{tabular}

Table 1: Electricity Consumption Devices and its Energy Consumption

This gives a summary of the energy demand during the day of appliances and their time of operation. The hourly demand of the village is shown in Figure 3 below. As presented in the figure, the proposed electricity requirements are high during two peak periods of the day - morning and evening time. The feasibility of additional appliances like a television set or a surplus energy storage scheme and trading with neighboring areas is a viable option due to surplus power generation.

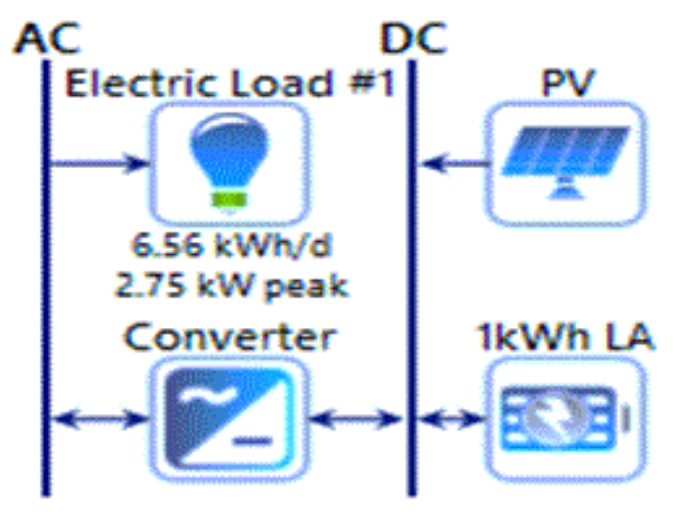

Figure 3: Hourly Demand for Mutate Masisi based on the aforementioned devices.

\section{System components and cost assumptions}

In this paper two different scenarios of operations are applied to cover the electricity demand of this community. These scenarios are built based on three main points which are: (i) reduce the system cost to the lowest possible value -the priority of the production will be 
Page 6 of 14

given to renewable energy sources so as to decrease the system cost (ii) and reduce the emissions - considering the environmental impact on life and welfare; (iii) and providing electricity to consumers efficiently without interruptions based on their energy demand. The conditions above are analysed using two hybrid systems, the system combines both conventional energy resource and renewable resource for two main reasons: To further encourage an easy and natural shift from a demand side perspective of the community to a more sustainable alternative. This translates into an easier transition from an already established pattern and energy demand habits. Also, the results gives a basis for comparative analysis on the costs and benefits associated with current energy resources and renewable resource.

The hybrid systems are: Photovoltaic system plus diesel generator for the time shortages and night time (for daily usage) and; Photovoltaics system plus battery storage to consume the excess produced energy via PV system and meet any deficiency periods and during the night (for daily usage).

\section{Net present cost of the system and $\mathrm{Co}_{2}$ emission cost}

The net present value can be calculate using equation 1 below

$C_{\mathrm{NPC}}=C_{\text {ann,tot }} / C R F\left(i, R_{\text {proj }}\right)$

Where:

$C_{\text {ann,tot }}$ : Total annualised cost,

CRF: Capital recovery cost,

$R_{\text {proj: }}$ Project lifetime ,

Interest rate.

The total $\mathrm{CO}_{2}$ emissions from hybrid system can be computed using equation 2

$t C \mathrm{O}_{2}=3.667 \times m_{\mathrm{f}} \times H V_{\mathrm{f}} \times C E F_{\mathrm{f}} \times X_{\mathrm{c}}$

Where:

$t \mathrm{CO}_{2}$ : Total amount of carbon dioxide,

$m_{\mathrm{f}}$. Fuel quantity,

$H V_{\mathrm{f}}$ : Fuel heating value,

$C E F_{\mathrm{f}}$ : Carbon emission factor (ton carbon/TJ),

$X_{\mathrm{c}}$ : Oxidised carbon fraction.

Another point should be taken into account that every $3.667 \mathrm{~g}$ of $\mathrm{CO}_{2}$ contains $1 \mathrm{~g}$ of carbon. The characteristics of the component parts for these two systems are summarized in Table 2 below:

\begin{tabular}{|l|l|l|}
\hline Components & Specification & Description \\
\hline PV Array & Size & $1,0.8,0.6,0.4 \mathrm{~kW}$ \\
\hline & Capital cost & $\$ 300$ \\
\hline & Replacement cost & $\$ 200$ \\
\hline & O\&M costs & $\$ 200$ \\
\hline Diesel Generator & Lifetime & $\$ 0.10$ \\
\hline & Size $(500 \mathrm{~kW})$ & Auto size to Load \\
\hline & Capital cost & $\$ 1500$ \\
\hline
\end{tabular}

\begin{tabular}{|l|l|l|}
\hline & Replacement cost & $\$ 200$ \\
\hline & O\&M costs & $\$ 200$ \\
\hline & Lifetime & $\$ 30$ \\
\hline Battery & Fuel cost & $\$ 200 /$ Liter \\
\hline & Type & Lead acid \\
\hline & Nominal voltage & $12 \mathrm{~V}$ \\
\hline & Nominal capacity & $1 \mathrm{kWh}$ \\
\hline & Maximum capacity & 83.4 Ah \\
\hline & Round trip efficiency & $80 \%$ \\
\hline & Capital cost & $\$ 300$ \\
\hline & Replacement cost & $\$ 300$ \\
\hline Converter & O\&M costs & $\$ 10$ year \\
\hline & Size & $1 \mathrm{~kW}$ \\
\hline & Capital cost & $\$ 300$ \\
\hline & O \& M cost & $\$ 60 /$ year \\
\hline & Replacement cost & $\$ 300$ \\
\hline & Efficiency & $95 \%$ \\
\hline & Lifetime & 16 years \\
\hline
\end{tabular}

Table 2: Component Parts and Characteristics.

\section{Simulation}

HOMER energy software from NREL is applied for the system simulation. The software can be used for different energy management scenarios such as off-grid, on-grid and mini-grid systems $[23,29]$. The main points of the paper can be investigated running this software as it assesses the system based on techno-economic view, following on previously established models [40-42]. In this paper, two different systems are designed using the main energy source (PV) and applied in a scenario to verify the best optimal solution for the village in a cheaper sustainable way [36-37].

The first scenario is the PV system with battery to store excess energy is used to meet any demand shortages. Four PV sizes are tested and the optimal sizing is selected and compared with the second scenario.

The second scenario is the PV system and diesel generator is added. The shortages during operation is matched using a diesel generator. The same four PV sizes used in the first scenario is applied and tested here and the optimal sizing is also selected and compared with the first scenario.

Finally, a comparison between the optimal solutions in the first and second scenarios has been presented. The criteria established between those two scenarios are: (a) the system cost (b) the renewable energy penetration and; (c) the demand satisfaction. Figures 4 and 5 below shows the two model scenario. 
Citation: Madziga M, Rahil A (2018) Electrification Using a Hybrid Microgrid System for Mutate Masisi Community-A Demand Side Response. J
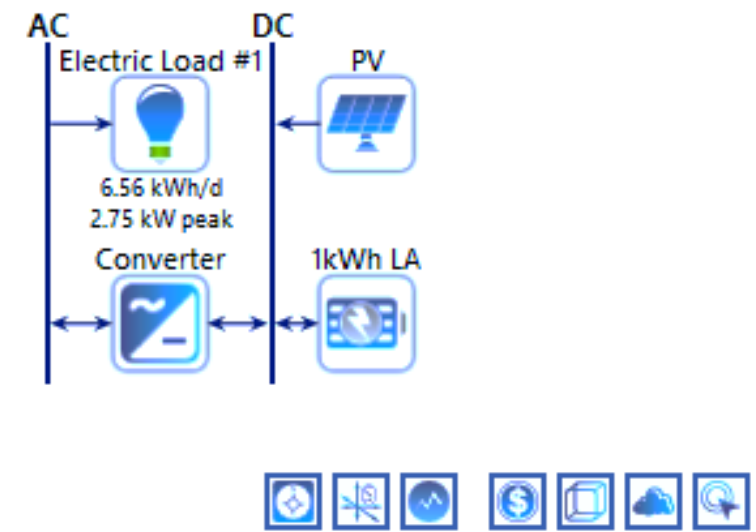

Figure 4: Pv-Battery Model.

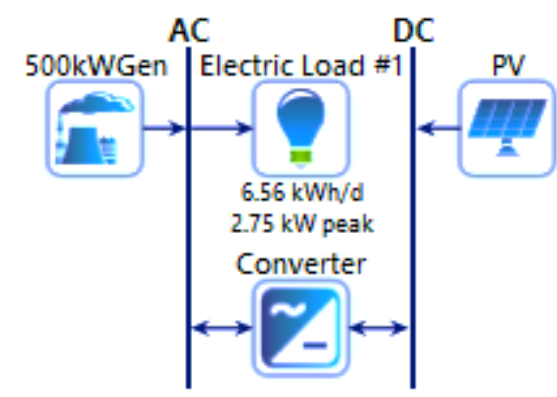

Figure 5: Pv-Diesel Generator Model.
In Figure 4 The model scenario shows the Hybrid Energy System when Battery is used which consists of the electric load at 6.56 $\mathrm{kWd} /$ day and the peak at $2.75 \mathrm{~kW}$. It has a $1 \mathrm{kWh}$ lead acid (LA) battery, a converter and a solar PV. In Figure 5: Hybrid Energy System when Diesel Generator is used consists of the electric load which is the same as in Figure 4, a converter, a solar PV and a $500 \mathrm{~kW}$ Diesel Generator set. The model scenarios were run for optimization in Homer software, which produces a series of lowest costs options which shows the overall costs of system. The results are presented below.

\section{Results}

\section{PV system with battery for energy storage}

Four different size of system has been applied and the result has been analysed for every size. These sizes are $1 \mathrm{~kW}, 0.8 \mathrm{~kW}, 0.6 \mathrm{~kW}$ and $0.4 \mathrm{~kW}$. Figure 6 below shows the total amount of energy production during the year of each system size. 
Citation: Madziga M, Rahil A (2018) Electrification Using a Hybrid Microgrid System for Mutate Masisi Community-A Demand Side Response. J

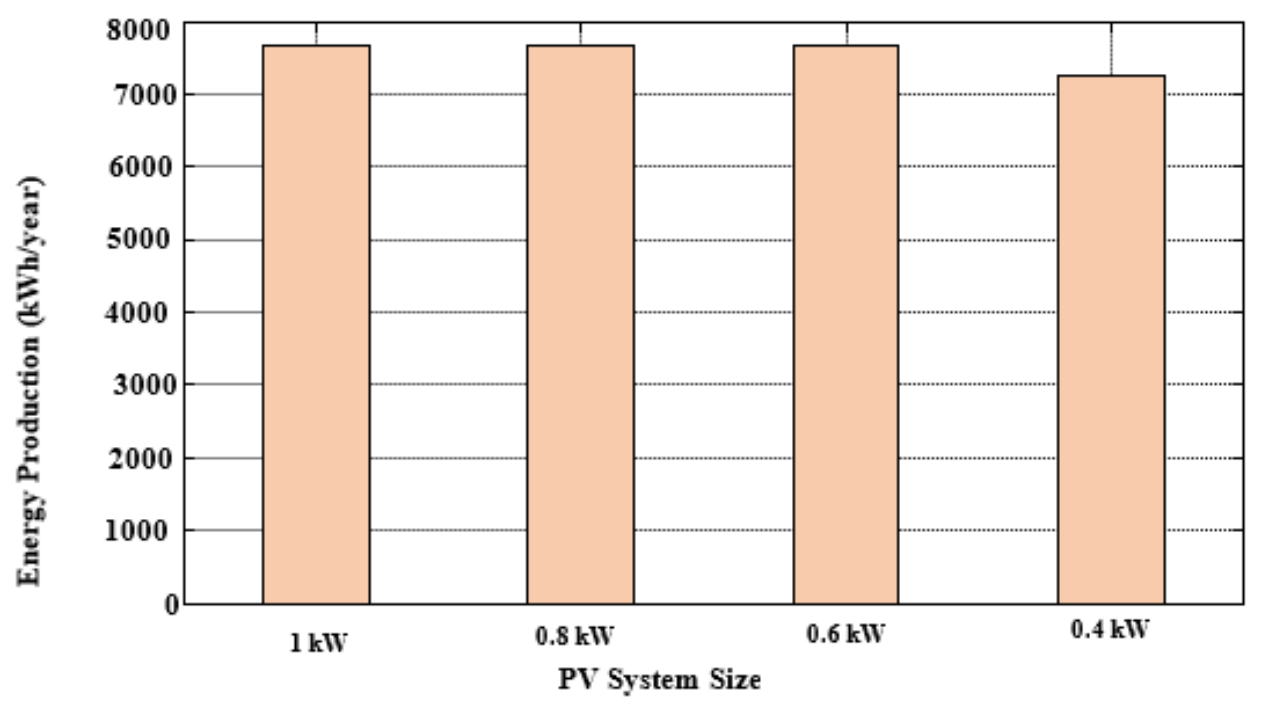

Figure 6: Energy Production of Different Sizes of PV Systems

The cost difference between these scenarios mainly comes from the number and the O\&M of the batteries in each scenario. For example, in the first scenario $(1 \mathrm{~kW}), 18$ cell will string whereas the number 19 will string in $0.4 \mathrm{~kW}$ size. In addition, due to the small size of the PV system in 0.4 and $0.6 \mathrm{Kw}$, the battery will take more time to be fully charge, which will lead to more operation and maintenance (O\&M) cost. Degradation is the main issue of the battery and has a direct relation with the period of operation. The operation and maintenance cost were $\$ 2,327, \$ 2,327 \$ 2,327$ and $\$ 2,456$ for the $1 \mathrm{~kW}, 0.8 \mathrm{~kW}, 0.6$ $\mathrm{kW}$, and $0.4 \mathrm{~kW}$ respectively. The O\&M cost of the PV system also has an inverse relationship with the PV system size even though the operation costs per year $(4,388 \mathrm{hrs} / \mathrm{yr})$ for all sizes is the same. This possibility is due to the fact that small sizes require more on-off connection to battery since it takes more time frame to fill the charge of battery.

This interpretation shows the difference between lifetime throughput of the battery in each scenario since the large size has longer lifetime $(11,234 \mathrm{kWh})$ compared with $11,666 \mathrm{kWh}$ in $0.4 \mathrm{~kW}$ size. The rest of calculations such as the unmet demand, energy price and total system cost per size are presented in Table 3.

\begin{tabular}{|l|l|l|}
\hline & $\begin{array}{l}\text { Photovoltaic } \\
\text { with Battery }\end{array}$ & $\begin{array}{l}\text { Photovoltaic with Diesel } \\
\text { Generator [without Battery] }\end{array}$ \\
\hline Unmet demand (kWh/year) & 1.14 & 0 \\
\hline Energy price (\$/kWh) & 0.87 & $\$ 3.34$ \\
\hline $\begin{array}{l}\text { Total net present cost }(\$ / \\
\text { year) }\end{array}$ & 26916.03 & $1,03,496.20$ \\
\hline
\end{tabular}

\begin{tabular}{|l|l|l|}
\hline $\mathrm{CO}_{2}$ Emissions (kg/year) & 0 & 6,928 \\
\hline
\end{tabular}

Table 3: Summary of the System under Different Sizes of Photovoltaics.

The result reveal that changing the PV size does not strongly affect the main function of the system since the unmet demand remains the same during the other three sizes. The unmet demand is equal only for one day demand during the year. With regards to the system component part, a decrease in the system size led to an increase in cost and also a corresponding increase in the system's battery size-which is required to meet any shortages due to the reduced PV size. Based on calculation above, first size $(1 \mathrm{~kW})$ can be considered to be economically efficient to meet the demand in the village despite the fact that more surplus energy will be wasted due to the small size of battery. Alternatively, the next step would be to increase the size of battery but increasing the battery size will further increase the system costs as well. Another option to combat this conundrum would be to introduce other household appliances in order to maximizing the surplus energy for demand-side response by adding Television and Radio sets, etc. The highest energy price costs come from the energy storage cost. For example, in $1 \mathrm{kw}$, the levelized cost of energy produced via PV system is $0.134 \$ / \mathrm{kWh}$ whereas the storage wear cost is $0.419 \$ / \mathrm{kWh}$. The rest comes from the annualized cost of other components.

\section{PV system with diesel generators and without battery}

In this scenario the battery storage is replaced by diesel generator to meet the demand during the PV shortage times. The same PV system 
Citation: Madziga M, Rahil A (2018) Electrification Using a Hybrid Microgrid System for Mutate Masisi Community-A Demand Side Response. J

sizes are used as with the first scenario. These were tested and two main points are observed even before the operation stage: the increase in $\mathrm{CO}_{2}$ emissions due to the fossil fuel usage and the amount of renewable energy wasted is higher than the last scenario - as a result of the lack of energy storage equipment. It is important to note that the
Mutate Masisi residents usually travel long distances of approximately 5 miles to buy fuel which leads to an increase in the fuel price above the normal rates. As at 2017, the fuel price in South Africa is fixed at around $1 \$ /$ litre. So the price could be considered $1.75 \$ /$ litre to cover the transportation cost $[32,44,65]$.

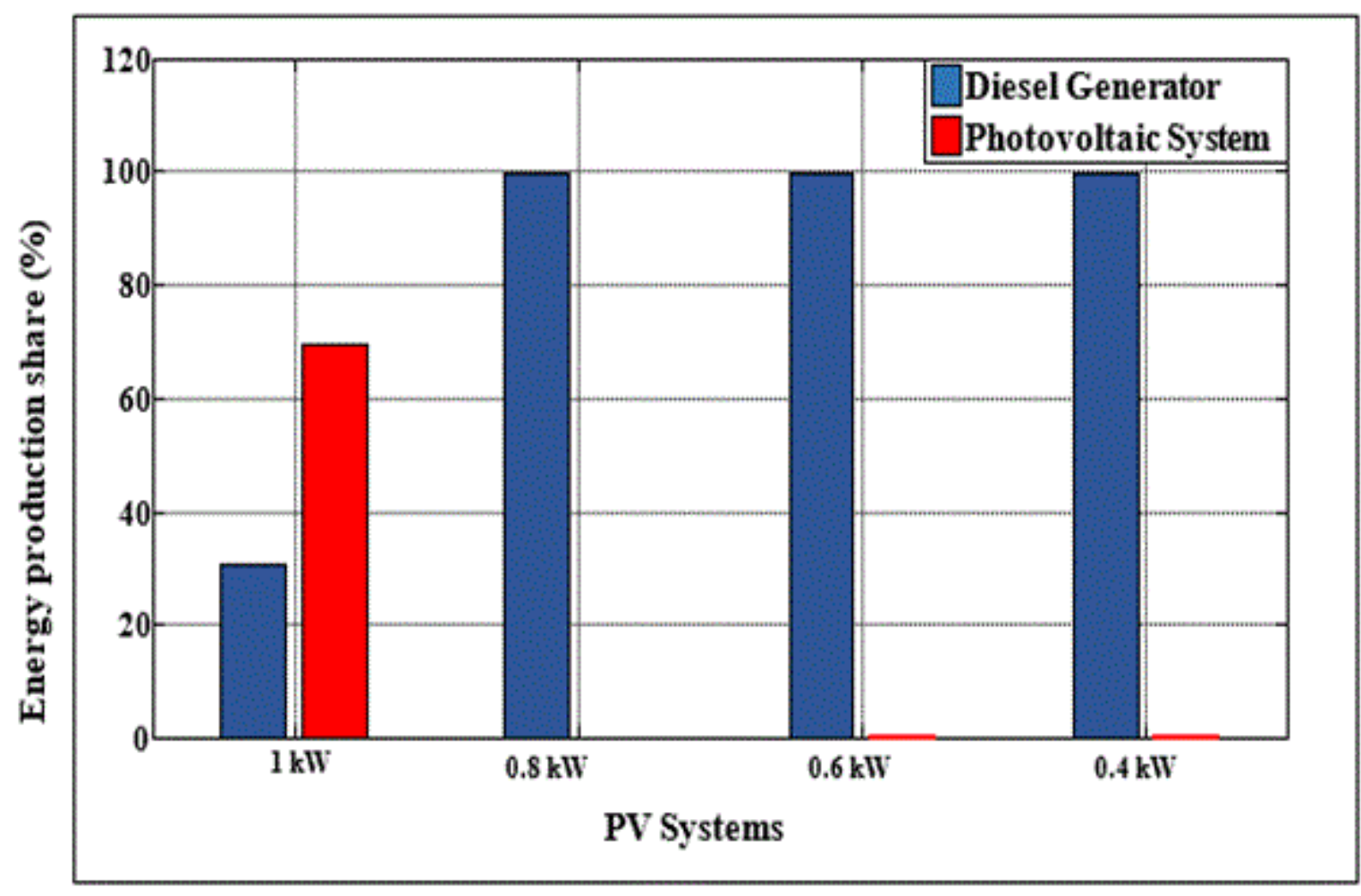

Figure 7: Sharing Cost of Each Component of the System.

In the Figure 7 above, when $1 \mathrm{~kW}$ of PV system plus diesel generator is applied, the energy production is more than double other $\mathrm{PV}$ sizes due to the highest share of the PV system in the total production. Regardless of the PV sizes $1 \mathrm{~kW}, 0.8 \mathrm{~kW}, 0.6 \mathrm{~kW}$ and 0.4 $\mathrm{kW}$ produce nearly the same amount of energy and most energy coming from diesel generator as shown in Figure 8 below. 
Citation: Madziga M, Rahil A (2018) Electrification Using a Hybrid Microgrid System for Mutate Masisi Community-A Demand Side Response. J

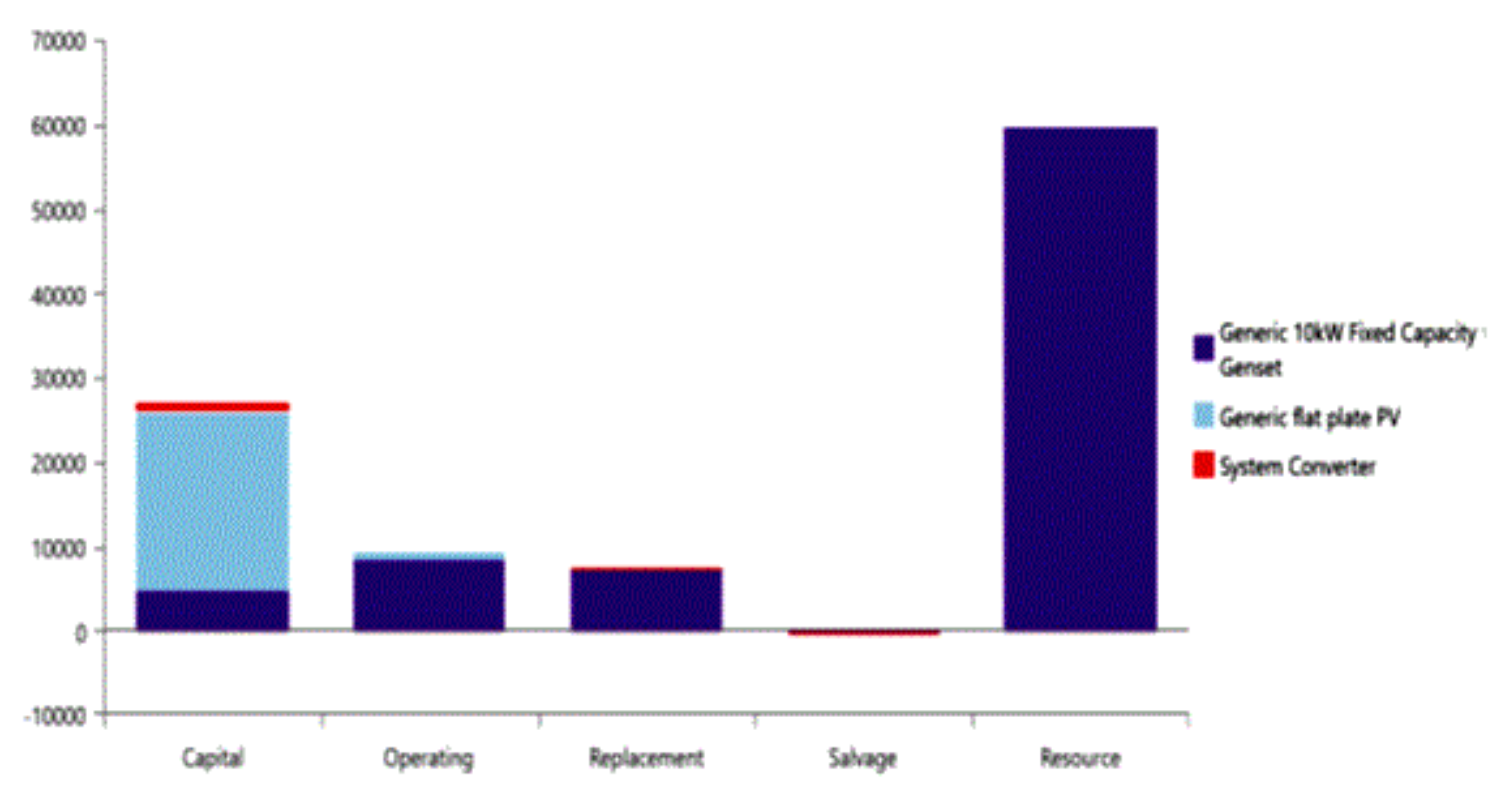

Figure 8: Energy Production of Different Sizes of PV Systems with a Diesel Generator.

The wasted energy is higher in $1 \mathrm{~kW}$ PV size compared with other scenarios due to the absence of energy storage equipment during the period of high PV productivity and low demand. Albeit, in other scenarios the wasted energy comes from a mismatch between the diesel generator production and demand since the diesel generator is operating at full capacity at any time of operation regardless of the required energy demand. The wasted energy will be $15734 \mathrm{kWh}, 4922$ $\mathrm{kWh}, 4922 \mathrm{kWh}$, and $4922 \mathrm{kWh}$ for $1,0.8,0.6$, and $0.4 \mathrm{~kW}$ system sizes respectively. In terms of demand satisfaction, all scenarios can meet the total demand without any deficiency due to the sustainable and efficient source of energy (diesel generator). The cost details of the total system under different PV sizes are presented in Figures 9 and 10.

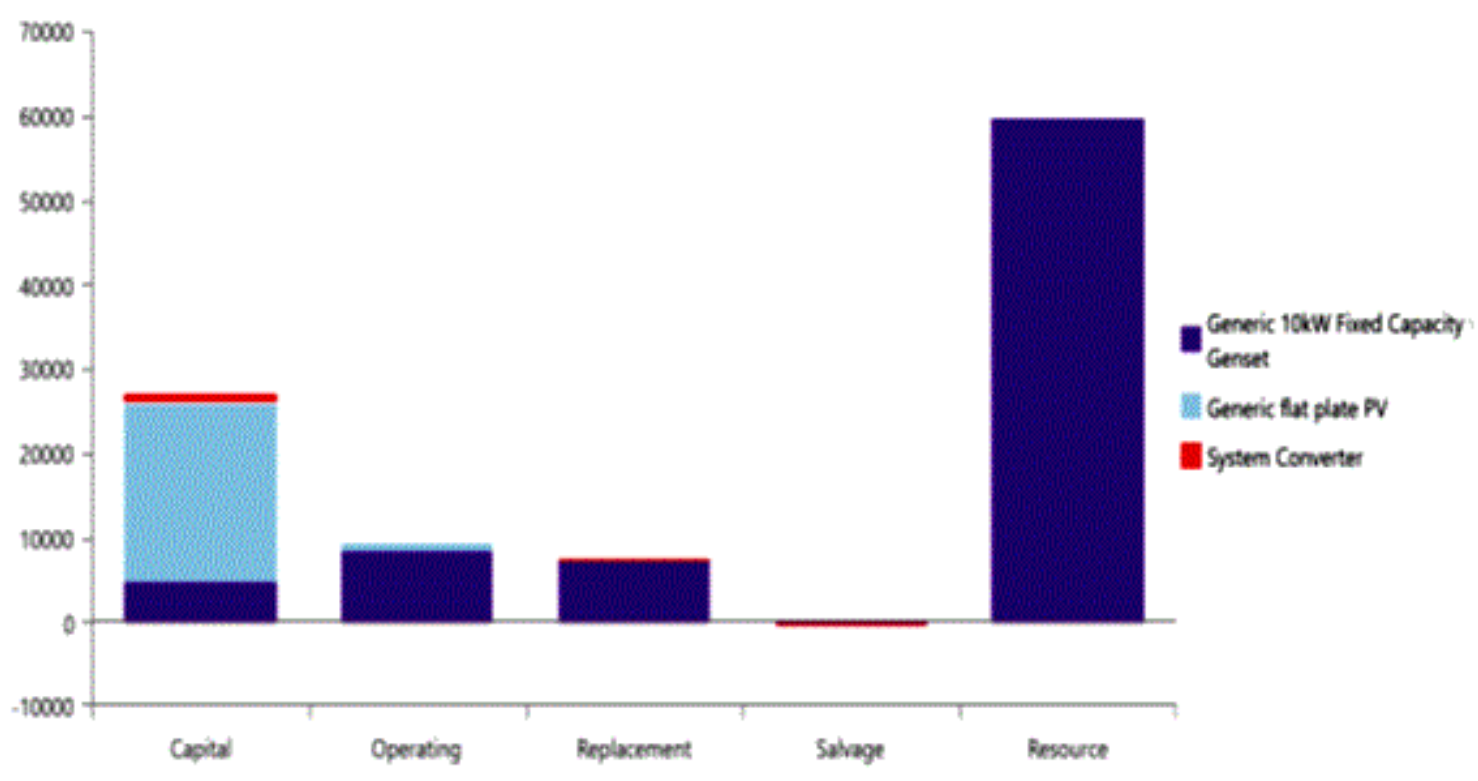

Figure 9: Cost Summary of the System (1 kW PV). 


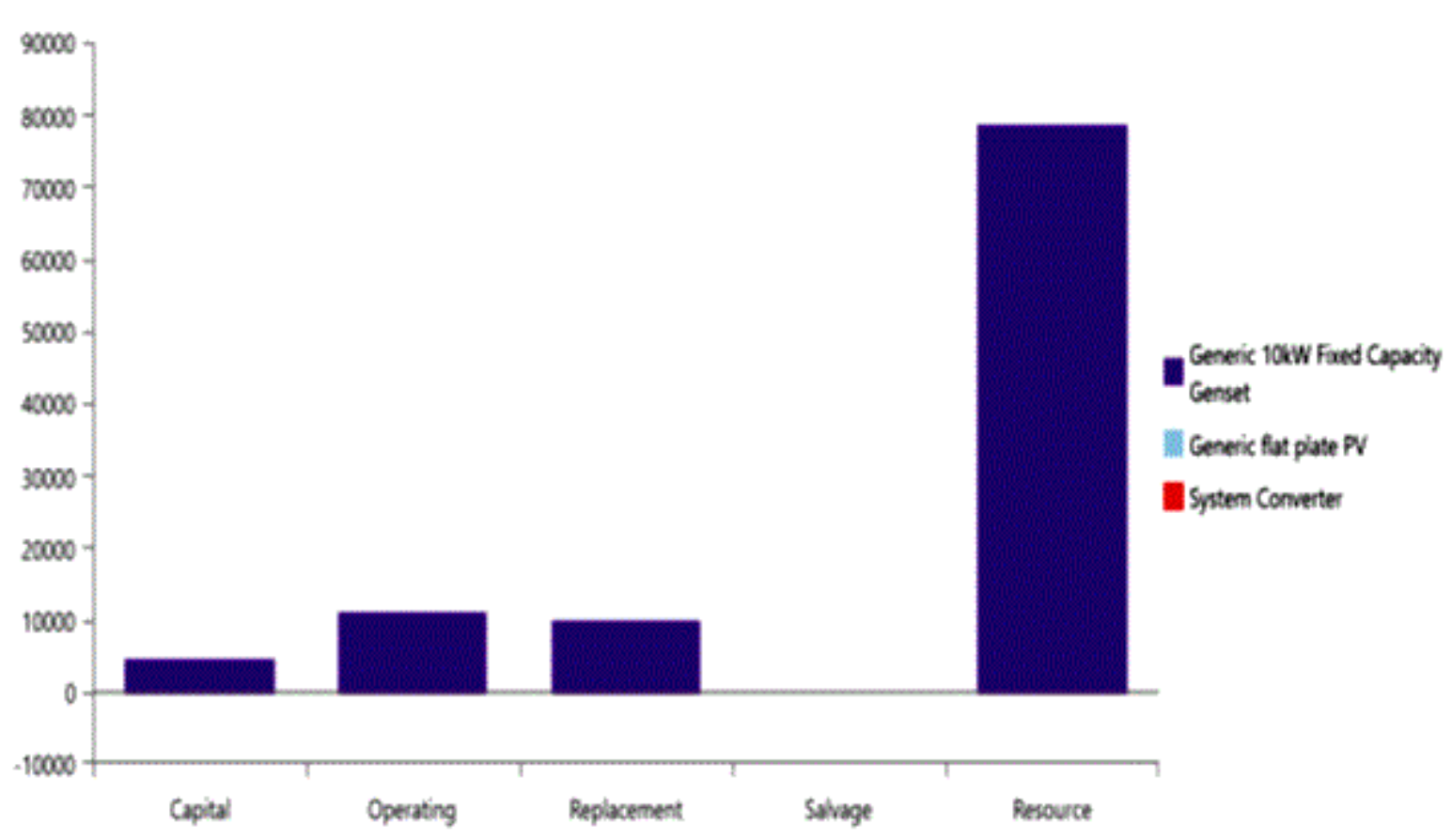

Figure 10: Cost Summary of the System (0.8 kW PV).

There is a clear share of the $1 \mathrm{~kW}$ PV in the total capital cost of the system since the size is relatively high compared with other tested sizes and the PV. The PV system $(1 \mathrm{~kW})$ is responsible for nearly $60 \%$ of the total production. However, in other scenarios, most costs come from diesel generator as in Figure 10 the resources cost represents the highest part of the cost in both sizes since the fuel price is quite high. Other sizes will be same as in Figure 10. The effect of diesel operation on the environment can be considered as one of main disadvantage of this scenario, especially if the system extended to include more villages. More cost can be added to the system due to the emissions and based on the social carbon cost (SCC) of South Africa. The carbon dioxide $\left(\mathrm{CO}_{2}\right)$ is 6.9 ton/year for first year in contrast with 9.1 ton/year in other scenarios. The difference in emissions can be linked with the operation hours of diesel generator in each scenario. For $1 \mathrm{~kW}$ scenario, diesel generators was running for 2,219 hrs/year whereas the running hours was estimated to be 2,920 hrs/year. Finally, the average price of energy per $\mathrm{kWh}$ was $3.34 \$ / \mathrm{kWh}$ in first scenario in contrast $3.4 \$ / \mathrm{kWh}$ in other scenarios. To sum up, first scenarios can be considered as a best scenario based on the system cost, pollution, energy price with more energy wasted compare with other scenarios.

\section{Discussion}

\section{Comparison between pv-battery scenario and pv-diesel generator scenario}

The comparison will include only $1 \mathrm{~kW}$ PV system since this was observed as the optimal mode of operation in each scenario. Based on the result above, the operation of photovoltaic with the battery has many advantages in contrast with its operation with diesel generator. There is a clear difference in system costs and energy price per kWh between different scenarios, regardless of its economic advantages. The operation of the photovoltaics with battery has no emissions-and this can be an added feature benefit in environmental factors. The comparison summary between these scenarios is given in Table 4 .

\begin{tabular}{|l|l|l|l|l|}
\hline $\begin{array}{l}\text { PV System } \\
\text { Size }\end{array}$ & $1 \mathrm{~kW}$ & $0.8 \mathrm{~kW}$ & $0.6 \mathrm{~kW}$ & $0.4 \mathrm{~kW}$ \\
\hline $\begin{array}{l}\text { Unmet } \\
\text { demand kWh/ } \\
\text { year }\end{array}$ & 1.14 & 1.14 & 1.14 & 1.22 \\
\hline $\begin{array}{l}\text { Energy price } \\
\text { (\$/kWh) }\end{array}$ & 0.87 & 0.874 & 0.882 & 0.888 \\
\hline $\begin{array}{l}\text { Total net } \\
\text { present cost } \\
\text { (\$/year) }\end{array}$ & 26916.03 & 27053.29 & 27311.95 & 27484.29 \\
\hline
\end{tabular}

Table 4: Comparison between the Operation of (I) Photovoltaic with Battery and (II) Photovoltaic with Diesel Generator [without battery].

\section{Conclusion}

The two scenarios (i) PV- Battery System and; (ii) PV-Diesel Generator System in an off-grid system highlights the potential of using a renewable energy based off-grid system for electrification. The comparison provides an effective method of increasing access of electricity to Mutate Masisi community. Both scenarios achieved the same job which is backing up the PV system at shortage times. Different sizes of PV has been used in each scenario and then the optimal size of each scenario was chosen. The criteria between these sizes are system cost, pollution and demand satisfaction. As it is presented in the result section, for the PV-Battery, $1 \mathrm{~kW}$ PV size was 
the optimal option between all sizes. The total cost of this size is the cheapest between all sizes which was around $\$ 26916.03$ compared with $\$ 27053.39 \$ 27311.95$ and $\$ 27484.29$ for $0.8 \mathrm{~kW}, 0.6 \mathrm{~kW}$ and $0.4 \mathrm{~kW}$. This leads to the cheapest energy price per kWh between all sizes. Other advantages can be noticed in $1 \mathrm{~kW}$ size related to the demand satisfaction and battery degradation. In PV-diesel scenario, same size $(1 \mathrm{Kw})$ was the optimum in contrast with other scenarios. The power share of the PV system in $1 \mathrm{~kW}$ size is nearly $60 \%$ of the total energy produced whereas the share is nearly zero in other scenarios. In terms of the pollution, $6 \mathrm{tCO}_{2} /$ year is released by $1 \mathrm{~kW}$ scenario compared with $9.6 \mathrm{tCO}_{2}$ in other scenarios. The only problem with scenario is the wasted energy will be higher than other scenarios. In a three-part structural comparison of system cost, pollution and demand satisfaction for the optimal PV sizes for both system scenarios, energy demand is adequately and sufficiently met without any a considerable interruption.

In the first scenarios (i) PV-Battery: the system size does not release any harmful emissions compared with nearly $6 \mathrm{tCO}_{2} /$ year in the second scenario (ii) PV-Diesel.

There is a huge different in cost between these scenarios. The cost in (i) PV-Battery represents $26 \%$ of the cost in (ii) PV- diesel scenario. Also, the (i) PV-Battery scenario enables for sourcing more energy storage units in high capacity with higher capacity storage systems such as batteries flywheel and hydrogen. This technique enhances the trend towards the application of renewable energy resources, increase in demand for storage systems and invariable lead to a reduction in storage techniques prices.

There is a direct correlation relationship between a community's productivity and economic growth, particularly in relation to sourcing for its energy sources. The electricity demand, consumption pattern and access are often determined and affected by the fluctuations in oil price (and other factors), and this in turn affects and impacts to a larger degree the availability of fuel for (diesel and petrol operated) generators; amongst this challenges lies the issues of emissions form these diesel and petrol operated generators, which poses as an environment threat. The use and adoption of the HRES (particularly with renewable energy resources) releases little to no pollutants as compared to their traditional counterparts [47], this is also reflected in this study and with the rise in emission penalties, more and more projects are seeking to adopt a more sustainable approach for cleaner environmental impact and preservation.

Future work and related research is prosed towards further optimization strategies in relation to dispatch and demand side management framework; installation of more appliance to accommodate surplus energy and applied energy storage techniques, which require further testing for comparison with battery. Alternatively, other renewable energy sources can be investigated such as wind speed and this can form the base for a wind turbine modelling in place or in conjunction with the solar PV in a techno-economic assessment.

\section{Acknowledgments}

MM and AR thanks the Faculty of Technology and the Institute of Energy and Sustainable Development (IESD) at De Montfort University, Leicester, UK for the support through the duration of the work. This work was supported by the simulation design of Homer Pro and Homer Grid modelling software by the National Renewable Energy Laboratory (NREL).

\section{References}

1. Alasseri R, Tripathi A, Rao TJ, Sreekanth KJ (2017) A review on implementation strategies for demand side management (DSM) in Kuwait through incentive-based demand response programs. Renewable and Sustainable Energy Reviews 77: 617-635.

2. Adam F (2010) Free Basic Electricity: A Better Life for All. Earthlife Africa Johannesburg, Republic of South Africa.

3. Aghajani GR, Shayanfar HA, Shayeghi H (2017) Demand side management in a smart micro-grid in the presence of renewable generation and demand response. Energy 126: 622-637.

4. Amutha WM, Rajini V (2016) Cost benefit and technical analysis of rural electrification alternatives in southern India using HOMER. Renewable and Sustainable Energy Reviews 62: 236-246.

5. Faruqui A, Kuczmowski T, Lilienthal P (1990) Demand Forecasting Methodologies: An Overview for Electric Utilities. Energy 15: 285-296.

6. Arteconi A, Hewitt NJ, Polonara F (2012) State of the Art Thermal Storage for Demand Side Management. Applied Energy 93: 371-389.

7. Bhattacharyya SC (2013) Financing Energy Access and Off-grid Electrification: A Review of Status, Options and Challenges. Renewable and Sustainable Energy Reviews 20: 462-472.

8. Belfkira R, Zhang L, Barakat G (2011) Optimal sizing study of hybrid wind/PV/diesel power generation unit. Solar Energy 85: 100-110.

9. Burman K, Keller J, Kroposki B, Lilienthal P, Slaughter R, et al. (2011) Renewable Power Options for Electrical Generation on Kaua'i: Economics and Performance Modeling. National Renewable Energy Lab (NREL), Golden, CO, USA.

10. Chai KH, Yeo C (2012) Overcoming energy efficiency barriers through systems approach-A conceptual framework. Energy Policy 46: 460-472.

11. Carus F (2016) What Next For Demand Side Response? Renewable Energy Focus 17: 1.

12. Chmiel Z, Bhattacharyya SC (2015) Analysis of off-grid electricity system at Isle of Eigg (Scotland): Lessons for developing countries. Renewable Energy 81: 578-588.

13. Chade D, Miklis T, Dvorak D (2015) Feasibility study of wind-tohydrogen system for Arctic remote locations-Grimsey island case study. Renewable Energy 76: 204-211.

14. Dufo-López R, Bernal-Agustín JL, Yusta-Loyo JM, Domínguez-Navarro JA, Ramírez-Rosado IJ, et al. (2011) Multi-objective optimization minimizing cost and life cycle emissions of stand-alone PV-wind-diesel systems with batteries storage. Applied Energy 88: 4033-4041.

15. Department of Energy, South Africa (2013) A Survey of Energy related Behaviour and Perceptions in South Africa. The Residential Sector 2012. Ministry of Energy, Department of Energy, Republic of South Africa. Accessed on 26 March, 2018.

16. Dorji T, Urmee T, Jennings P (2012) Options for off-grid electrification in the Kingdom of Bhutan. Renewable Energy 45: 51-58.

17. Elhadidy MA, Shaahid SM (2004) Promoting applications of hybrid (wind + photovoltaic + diesel + battery) power systems in hot regions. Renewable Energy 29: 517-528.

18. Electricity Demand Savings from Distributed Solar Photovoltaics. Accessed on March 23, 2018.

19. Magadla RK (2016) Forecasts for electricity demand in South Africa (2014-2050) using the CSIR sectoral regression model.

20. European Commission (2014) A Strategy for Smart, Sustainable and Inclusive Growth.

21. Goel S, Sharma R (2017) Performance Evaluation of Standalone, Grid Connected and Hybrid Renewable Energy Systems for Rural Application: A Comparative Review. Journal of Renewable and Sustainable Energy Reviews 78: 1378-1389.

22. Ghaib K, Ben-Fares FZ (2017) A Design Methodology of Stand-Alone Photovoltaic Power Systems for Rural Electrification 148: 1127-1141.

23. Givler T, Lilienthal P (2005) Using HOMER Software, NREL's Micropower Optimization Model to Explore the Role of Gen-sets in Small Solar Power Systems. Case Study: Sri Lanka. 
24. Good N, Ellis KA, Mancarella P (2017) Review and classification of barriers and enablers of demand response in the smart grid. Renewable and Sustainable Energy Reviews 72: 57-72.

25. Holloway JP, Mokilane P, Makhany S, Magadla T, Koen R (2016) Forecasts for Electricity Demand in South Africa 2014-2050 using the CSIR Sectoral Regression Model. Project Report Eskom.

26. Hosseinalizadeh R, Shakouri GH, Amalnick SM, Taghipour P (2016) Economic Sizing of a Hybrid (PV-WT-FC) Renewable Energy System (HRES) for Stand-Alone Usages by an Optimization-Simulation Model: Case study of Iran. Renewable and Sustainable Energy Reviews 54: 139-150.

27. Hossain M, Mekhilef S, Olatomiwa L (2017) Performance Evaluation of a Stand-Alone PV-Wind-Diesel-Battery Hybrid System Feasible for a Large Resort Center in South China Sea, Malaysia. Sustainable Cities and Society 28: 358-366.

28. Iaquaniell G, Montanari W, Salladini A (2017) Standalone CSP-DG System for Electrification of Remote Areas and Desalinated Water Supply. Journal of Solar Energy 157: 1056-1063.

29. Johnson N, Glassmire J, Lilienthal P (2013) Techno-Economic Design of Off-Grid Domestic Lighting Solutions Using HOMER. Proceedings of the ASME Design Engineering Technical Conference 3. Accessed on March 23, 2018.

30. Jose L, Bernal-Agustin LJ, Dufo-Lopez R (2005) Design and Control Strategies of PV-Diesel Systems Using Genetic algorithms. Journal of Solar Energy 79: 33-46.

31. Jose L, Bernal-Agustin LJ, Dufo-Lopez R (2009) Multi-Objective Design of PV-Wind-Diesel-Hydrogen-Battery Systems. Journal of Renewable Energy 33: 2559-2572.

32. Jamal N (2015) Options for the Supply of Electricity to Rural Homes in South Africa. Journal of Energy in Southern Africa 26: 3.

33. Koutroulis E, Kololotsa D, Potirakis A, Kalaitzakis K (2006).

34. Krishan O (2018) Design and Techno-Economic Analysis of a HRES in a Rural Village. Procedia Computer Science 125: 321-328.

35. Kim H, Jung TY (2018) Independent solar photovoltaic with Energy Storage Systems (ESS) for rural electrification in Myanmar. Renewable and Sustainable Energy Reviews 82: 1187-1194.

36. Kumar P, Pukale R, Kumabhar N, Patil U (2016) Optimal design configuration using HOMER. Procedia Technology 24: 499-504.

37. Kaur T, Segal R (2017) Designing Rural Electrification Solution Considering Hybrid Energy Systems for Papua New Guinea. Energy Procedia 110: 1-7.

38. Kolhe ML, Ranaweera KI, Gunawardana AS (2015) Techno-economic sizing of off-grid hybrid renewable energy system for rural electrification in Sri Lanka. Sustainable Energy Technologies and Assessments 11: 53-64.

39. Khare V, Nema S, Baredar P (2016) Solar-wind hybrid renewable energy system: A review. Renewable and Sustainable Energy Reviews 58: 23-33.

40. Kaabeche A, Ibtiouen R (2014) Techno-economic optimization of hybrid photovoltaic / wind / diesel / battery generation in a stand-alone power system. Solar Energy 103: 171-182.

41. Lao C, Chungpaibulpatana S (2017) Techno-economic analysis of hybrid system for rural electrification in Cambodia. Energy Procedia 138 524-529.

42. Lambert T, Gilman P, Lilienthal P (2005) Micropower system modeling with HOMER. Integration of Alternative Sources of Energy 16: 379-418.

43. Lorca Á, Prina J (2014) Power portfolio optimization considering locational electricity prices and risk management. Electric Power Systems Research 109: 80-89.

44. Masekoameng KE, Simalenga TE, Saidi T (2005) Household energy needs and utilization patterns in the Giyani rural communities of Limpopo Province, South Africa. Journal of Energy in Southern Africa 16: 4-9.

45. Manral L, Harrigan KR (2018) The logic of demand-side diversification: Evidence from the US telecommunications sector, 1990-1996. Journal of Business Research 85: 127-141.
46. Mandelli S, Barbieri J, Mereu R, Colombo E (2016) Off-grid systems for rural electrification in developing countries: Definitions, classification and a comprehensive literature review. Renewable and Sustainable Energy Reviews 58: 1621-1646.

47. Maleki A, Askarzadeh A (2014) Optimal sizing of a PV/wind/diesel system with battery storage for electrification to an off-grid remote region: A case study of Rafsanjan, Iran. Sustainable Energy Technologies and Assessments 7: 147-153.

48. Müller T, Möst D (2018) Demand Response Potential: Available when Needed?. Energy Policy 115: 181-198.

49. Marwan M, Ledwich G, Ghosh A (2014) Demand-side response model to avoid spike of electricity price. Journal of Process Control 24: 782-789.

50. Neves D, Silva CA, Connors S (2014) Design and implementation of hybrid renewable energy systems on micro-communities: a review on case studies. Renewable and Sustainable Energy Reviews 31: 935-946.

51. Olatomiwa L, Mekhilef S, Huda AS, Ohunakin OS (2015) Economic evaluation of hybrid energy systems for rural electrification in six geopolitical zones of Nigeria. Renewable Energy 83: 435-446.

52. Qolipour M, Mostafaeipour A, Tousi OM (2017) Techno-economic feasibility of a photovoltaic-wind power plant construction for electric and hydrogen production: A case study. Renewable and Sustainable Energy Reviews 78: 113-123.

53. Kanase-Patil AB, Saini RP, Sharma MP (2010) Integrated renewable energy systems for off grid rural electrification of remote area. Renewable Energy 35: 1342-1349.

54. Ranaboldo M, Ferrer-Martí L, García-Villoria A, Moreno RP (2013) Heuristic indicators for the design of community off-grid electrification systems based on multiple renewable energies. Energy 50: 501-512.

55. Rehman S, Alam MM, Meyer JP, Al-Hadhrami LM (2012) Feasibility study of a wind-pv-diesel hybrid power system for a village. Renewable Energy 38: 258-268.

56. Rajbongshi R, Borgohain D, Mahapatra S (2017) Optimization of PVbiomass-diesel and grid base hybrid energy systems for rural electrification by using HOMER. Energy 126: 461-474.

57. Rahil A, Gammon R (2017) Dispatchable hydrogen production at the forecourt for electricity demand shaping. Sustainability 9: 1785.

58. Rajbongshi R, Borgohain D, Mahapatra S (2017) Optimization of PVbiomass-diesel and grid base hybrid energy systems for rural electrification by using HOMER. Energy 126: 461-474.

59. Sharifi R, Fathi SH, Vahidinasab V (2017) A review on Demand-side tools in electricity market. Renewable and Sustainable Energy Reviews 72: $565-572$

60. Singh A, Baredar P, Gupta B (2015) Computational simulation and optimization of a solar, fuel cell and biomass hybrid energy system using HOMER pro software. Procedia Engineering 127: 743-750.

61. Scheubel C, Zipperle T, Tzscheutschler P (2017) Modeling of industrialscale hybrid renewable energy systems (HRES)-The profitability of decentralized supply for industry. Renewable Energy 108: 52-63.

62. Sawle Y, Gupta SC, Bohre AK (2017) Review of hybrid renewable energy systems with comparative analysis of off-grid hybrid system. Renewable and Sustainable Energy Reviews.

63. Shezan SKA, Julai S, Kibria MA, Ullah KR, Saidur R, et al. (2016) Performance Analysis of an Off-grid Wind-PV-Diesel-Battery Hybrid Energy System feasible for Remote Areas.

64. US Department of Energy (2006) Benefits of Demand Response in Electricity Markets and Recommendations for Achieving Them - A Report to the United States Congress Pursant to Section 1252 of the Energy Policy Act of 2005.

65. Voice of Africa News Forum (2017) Remote South Africa Village Gets Electricity for First Time - in 2014. Accessed 15th December, 2017.

66. The World Bank (2014) Electric Power Consumption (kWh per capita).

67. Wu Z, Xia X (2017) A Portfolio Approach of Demand Side Management. IFAC-Papers on Line 50: 171-176.

68. Warren P (2017) Transferability of demand-side policies between countries. Energy Policy 109: 757-766. 
Citation: Madziga M, Rahil A (2018) Electrification Using a Hybrid Microgrid System for Mutate Masisi Community-A Demand Side Response. J Environ Anal Toxicol 8: 590. doi:10.4172/2161-0525.1000590

Page 14 of 14

69. Yilmaz S, Dincer F (2017) Optimal design of hybrid PV-Diesel-Battery systems for isolated lands: A case study for Kilis, Turkey. Renewable and Sustainable Energy Reviews 77: 344-352.

70. Yu Y (2010) Policy redesign for solving the financial bottleneck in demand side management (DSM) in China. Energy Policy 38: 6101-6110.
71. Zahboune H, Zouggar S, Krajacic G, Varbanov PS, Elhafyani M, et al. (2016) Optimal hybrid renewable energy design in autonomous system using Modified Electric System Cascade Analysis and Homer software. Energy Conversion and Management 126: 909-922. 